\title{
Neonatal transient pseudohypoparathyroidism: could it be included among inactivating parathyroid hormone (PTH)/PTH-related protein signalling disorders?
}

Domenico Umberto De Rose, MD, Alessandro Perri, MD, Francesca Gallini, MD, Francesca Priolo, MD, Eloisa Tiberi, MD, Giovanni Vento, $M D$, Enrico Zecca, MD

Division of Neonatology, Department of Pediatrics, Fondazione Policlinico Universitario "A. Gemelli" IRCSS Catholic University of the Sacred Heart, Rome, Italy
Received: 27 January, 2019

Revised: 4 March, 2019

Accepted: 11 March, 2019

\section{Address for correspondence:} Domenico Umberto De Rose, MD Division of Neonatology, Department of Pediatrics, Fondazione Policlinico Universitario "A. Gemelli" IRCSS-Catholic University of the Sacred Heart, Rome, Italy

Tel: +39-6-3015-4475/5165

Fax: +39-6-3052-751

E-mail: derosedomenicoumberto@ gmail.com

https://orcid.org/0000-0002-90769838
We report a case of transient pseudohypoparathyroidism in a full-term newborn that presented at 20 hours of life with hypocalcemic seizures, hyperphosphatemia and raised parathormone levels. The diagnosis of pseudohypoparathyroidism was made according to biochemical investigations. The infant was treated with calcium supplementation and vitamin D analog therapy, and he remained stable and symptom-free with normal serum biochemistries during follow-up. We suggest that transient pseudohypoparathyroidism of the newborn (ntPHP) might be included among inactivating parathyroid hormone (PTH)/PTH-related protein signaling disorders as defined by the classification schema recently proposed by the European Pseudohypoparathyroidism Network. To the best of our knowledge, this is the first report in which the new classification has been applied to a case of ntPHP.

Keywords: Pseudohypoparathyroidism, Pseudohypoparathyroidism, Hypocalcemic seizures, Newborn, Inactivating PTH/PTH-related protein signaling disorder, Personalized medicine

\section{Introduction}

Pseudohypoparathyroidism (PHP) is a heterogeneous group of disorders in which resistance to parathyroid hormone $(\mathrm{PTH})$ in the proximal renal tubules leads to hypocalcemia, hyperphosphatemia, and impaired $1,25(\mathrm{OH})_{2}$ vitamin D production. The incidence of PHP has been reported to be 0.79 per 100 patients. ${ }^{1)}$ The disease was first described and named by Fuller Albright and colleagues in 1942. ${ }^{2)}$ Albright's hereditary osteodystrophy (AHO) is described as an associated clinical entity with PHP characterized by brachydactyly, subcutaneous ossifications, round face, short stature, obesity, and cognitive impairment.

Herein, we report a newborn with transient PHP who presented at 20 hours of life with multifocal hypocalcemic seizures. We discuss this rare entity with reference to the recent literature.

\section{Case report}

A male newborn was delivered at 37 weeks' gestational age by caesarean section without labor (birth weight 3,395 g, appropriate for gestational age according to the INeS Charts ${ }^{3)}$ ). Apgar score was $8 / 8$ at 1/5 minutes, respectively. After delivery, he developed transient tachypnea of the newborn requiring supplemental oxygen via nasal cannula for 4 hours. His parents were reportedly healthy, of normal stature and without any history of consanguinity. 
The antenatal period was reported as uneventful. At 20 hours of life, he presented multifocal generalized seizures lasting less than one minute. A metabolic screening revealed blood glucose 82 $\mathrm{mg} / \mathrm{dL}$ (normal, $>46 \mathrm{mg} / \mathrm{dL}$ ), serum calcium $6.7 \mathrm{mg} / \mathrm{dL}$ (normal, 8.6-10.2 mg/dl), phosphorus $9.4 \mathrm{mg} / \mathrm{dL}$ (normal, $4.0-7.0 \mathrm{mg} /$ $\mathrm{dL}$ ), and magnesium $2.0 \mathrm{mg} / \mathrm{dL}$ (normal, $1.8-2.4 \mathrm{mg} / \mathrm{dL}$ ). Predisposing factors for early-onset hypocalcemia, including prematurity, intrauterine growth retardation, maternal diabetes, birth asphyxia, and maternal use of antiepileptic drugs, were not present. Sepsis was ruled out. Cranial ultrasound revealed mild left hydrocephalus, which did not require any treatment. The parents reported that the patient's brother (6 years old at the time of writing) had hypocalcemia and similar symptoms at birth that required supplementation with calcium and vitamin $D$ analogs until 3 months of life.

In consideration of his symptomatic hypocalcemia, the child was treated with $10 \%$ calcium gluconate $(2 \mathrm{~mL} / \mathrm{kg}$ given by intravenous infusion over 15 minutes) while monitoring the heart rate during the infusion. After a continuous infusion of $10 \%$ calcium gluconate over 48 hours $(80 \mathrm{mg} / \mathrm{kg} /$ day $)$, he was received oral $10 \%$ calcium gluconate $(40 \mathrm{mg} / \mathrm{kg} /$ day $)$ and calcifediol (800 IU/day). The patient was fed on breast milk plus term formula for the first 3 days and then only breast milk thereafter. No more seizures were observed. Despite supplementation, hypocalcemia persisted (serum calcium: $6.8 \mathrm{mg} / \mathrm{dL}$ after 72 hours of supplementation) (Table 1), so the following additional tests were performed: serum PTH by radioimmunoassay was $94.3 \mathrm{pg} / \mathrm{mL}$ (normal, $14.0-72.0 \mathrm{pg} / \mathrm{mL}$ ), 25-hydroxyvitamin D was $70.1 \mathrm{ng} / \mathrm{mL}$ (normal, 31.0-100.0 ng/ $\mathrm{mL}$ ), calcitonin was $<3.0 \mathrm{pg} / \mathrm{mL}$ (normal, $<10 \mathrm{pg} / \mathrm{mL}$ ), thyroidstimulating hormone (TSH) was $2.69 \mu \mathrm{UI} / \mathrm{mL}$ (normal, 0.35 $8.00 \mu \mathrm{UI} / \mathrm{mL}$ ), serum-free T4 was $9.2 \mathrm{pg} / \mathrm{mL}$ (normal, $8.5-16.5$ $\mathrm{pg} / \mathrm{mL}$ ) and serum-free T3 was $3.9 \mathrm{pg} / \mathrm{mL}$ (normal, 2.4-4.2 pg/ $\mathrm{mL}$ ). Urine calcium to creatinine ratio was within normal limits (normal, $<0.18$ ). Physical examination was unremarkable, and there were no stigmata of $\mathrm{AHO}$, rachitic rosary, or congenital malformations.

Considering his persistent hypocalcaemia, hyperphospha-

Table 1. Laboratory data of our patient

\begin{tabular}{|c|c|c|c|}
\hline Serum biochemistry test & Day of life & Result & Normal ranges \\
\hline Calcium (mg/dL) & $1 s t$ & 6.7 & $8.6-10.2$ \\
\hline Phosphorus (mg/dL) & $1 \mathrm{st}$ & 9.4 & $4.0-7.0$ \\
\hline Magnesium (mg/dL) & $1 \mathrm{st}$ & 2.0 & $1.8-2.4$ \\
\hline Calcium (mg/dL) & 4th & 6.8 & $8.6-10.2$ \\
\hline PTH $(p g / m L)$ & 4th & 94.3 & $14.0-72.0$ \\
\hline 25-hydroxyvitamin D (ng/mL) & 4th & 70.1 & $31.0-100.0$ \\
\hline Calcitonin $(\mathrm{pg} / \mathrm{mL})$ & 4 th & $<3.0$ & $<10$ \\
\hline TSH (thyrotropin) ( $\mu \mathrm{UI} / \mathrm{mL})$ & 4th & 2.69 & $0.35-8.00$ \\
\hline Free T4 (thyroxine) (pg/mL) & 4th & 9.2 & $8.5-16.5$ \\
\hline Free T3 (triiodothyronine) (pg/mL) & 4th & 3.9 & $2.4-4.2$ \\
\hline Calcium (mg/dL) & 9th & 8.6 & $8.6-10.2$ \\
\hline Phosphorus (mg/dL) & 9th & 7.0 & $4.0-7.0$ \\
\hline PTH $(p g / m L)$ & 30th & 50.9 & $14.0-72.0$ \\
\hline
\end{tabular}

PTH, parathyroid hormone; TSH, thyroid-stimulating hormone. temia, high serum PTH levels, and lack of stigmata of AHO, we considered PHP type Ib, a diagnosis supported by his brother's clinical history, which was possibly the same disease with a genetic origin. The serum calcium and phosphorus returned to within normal limits after 8 days of supplementation, and serum PTH returned to normal $(50.9 \mathrm{pg} / \mathrm{mL})$ at the 30th day of life. His parents declined further examinations, so PTH infusion and molecular analysis of the GNAS gene could not be performed. The child was discharged in good clinical condition on calcifediol and calcium supplementation until the age of 30 days (calcifediol $800 \mathrm{IU} /$ day and calcium $40 \mathrm{mg} / \mathrm{kg} /$ day). He had no further seizures and normal serum electrolyte levels until three months of age, when he was lost to follow-up.

\section{Discussion}

PHP, a condition characterized by hypocalcemia, hyperphosphatemia, and elevated serum PTH levels, is associated with a receptor or post receptor defect resulting in end-organ unresponsiveness to PTH.

Several types of PHP that have been classically described include PHP-Ia, PHP-Ib, PHP-Ic, PHP-II and pseudo-PHP (pPHP), and they are classified according to the following: presence or absence of $\mathrm{AHO}$, in vivo response to exogenous $\mathrm{PTH}$, and measurement of Gsa protein activity in peripheral erythrocyte membranes in vitro. In PHP type Ia (PHP-Ia, OMIM $\# 103580$ ), patients have AHO features and multiple hormone resistance in hormones requiring Gsa-coupled receptors (including PTH, thyroid-stimulating hormone, growth hormone-releasing hormone, and calcitonin). Patients have a failure to increase both urinary cAMP and urinary phosphate excretion in response to PTH infusion, decreased erythrocyte Gs activity, and a GNAS mutation in the maternally-derived allele. ${ }^{4)}$ In contrast to PHP-Ia, patients affected by PHP type Ib (PHP-Ib, OMIM \#603233) typically present only with PTHresistant hypocalcemia and hyperphosphatemia, no evidence of AHO, a normal erythrocyte Gs activity and a deletion in the differentially methylated region of the GNAS locus. ${ }^{4)}$ PHPIa and PHP-type Ic (PHP-Ic, OMIM \#612462) are clinically identical, and patients in these groups both have the presence of $\mathrm{AHO}$ and multiple hormone resistance, although Gsa activity is normal in patients with PHP-Ic. ${ }^{5)}$ In PHP type II (PHP-II, OMIM \#203330), patients have isolated renal PTH resistance, lack AHO features, a normal erythrocyte Gs activity and a normal urinary cAMP generation in response to PTH infusion, but the urinary excretion of phosphate is impaired. ${ }^{4)}$

pPHP (OMIM \# 612463) is an inherited disorder named for its similarity to PHP in presentation. pPHP patients have AHO without endocrine abnormalities, a normal cellular cAMP response to PTH infusion, decreased erythrocyte Gs activity and a paternal inherited GNAS mutation. ${ }^{4}$

This 'old' classification of PHP, nevertheless, fails to differentiate PHP patients with different clinical and molecular findings. ${ }^{6)}$ A new classification has been recently proposed by 
the European Pseudohypoparathyroidism Network (EuroPHP Network) to cover all disorders of the PTH pathway. Inactivating $\mathrm{PTH} / \mathrm{PTH}$-related protein signaling disorder (iPPSD) is the new name proposed for these disorders in which a genetic defect leads to deficient PTH receptor (PTH1R) signaling in the kidney. iPPSDs can be further divided into subtypes: iPPSD1 to iPPSD6. For the diagnosis of iPPSD, major criteria (PTH resistance, ectopic ossification and brachydactyly type E) and minor criteria (TSH resistance, other hormonal resistances, motor and cognitive retardation or impairment, intrauterine and postnatal growth retardation, obesity/overweight, flat nasal bridge and/or maxillary hypoplasia and/or round face) have been proposed. A minimum of one major criterion is mandatory for the clinical diagnosis of iPPSD. ${ }^{7}$ )

In the neonatal population, the exact incidence of pseudohypoparathyroidism is unknown.A Pubmed (MEDLINE) database search from 1995 onwards was performed using the medical subject headings $[\mathrm{MeSH}]$ terms 'pseudohypoparathyroidism' and 'newborn', and only papers reporting transient pseudohypoparathyroidism of the newborn that were not due to fetal or maternal risk factors were selected. This search revealed only a few case reports of PHP (Table 2).

In 1995, Minagawa et al. ${ }^{8}$ reported three newborns with "transient pseudohypoparathyroidism of the neonate" presenting with seizures at 10 and 11 days of age. The biochemical features in these patients included transient hypocalcemia and hyperphosphatemia, elevated PTH levels, and normal magnesium and vitamin D levels for age. To diagnose pseudohypoparathyroidism type I, intravenous human PTH infusions were performed. All three newborns showed an increase in serum alkaline phosphatase activity, suggesting PTH stimulation of osteoblasts. They were initially treated with calcium lactate or calcitriol, and serum calcium and PTH levels returned to normal before the age of 6 months.

Notably, most of the PHP patients reported in the literature were male, as was our patient, ${ }^{8-15)}$ and the reason for the male predominance is unknown. None of the reported newborns (including our patient) had AHO features in the first months of life. All patients with severe symptomatic hypocalcemia were treated with calcium and vitamin D metabolites to maintain serum calcium levels within the reference range for age and to normalize PTH levels.

Applying iPPSD criteria to these cases, one can observe that they all had persistent hypocalcemia and PTH resistance but no other major or minor criteria. Nevertheless, we speculate whether neonatal transient pseudohypoparathyroidism (ntPHP) could be included among iPPSDs, specifically in the group of unknown molecular defects. Clinical manifestations in the neonatal age differ markedly from those in older children, and skeletal abnormalities typical of AHO may not be apparent in the neonatal period despite detailed physical and radiological examination. According to the new iPPSD criteria, PTH infusion test must be performed in challenging cases, although there are no evidences showing the safety of this test in newborns.

In our patient with early-onset hypocalcemia, predisposing

Table 2. Summary of last case reports of neonatal transient pseudo-hypoparathyroidism

\begin{tabular}{|c|c|c|c|c|c|c|c|c|c|c|}
\hline $\begin{array}{l}\text { No. of } \\
\text { patients }\end{array}$ & $\begin{array}{l}\text { Age at } \\
\text { onset } \\
\text { (day) }\end{array}$ & Sex & $\begin{array}{l}\text { Gestational } \\
\text { age (wk) }\end{array}$ & Country & $\begin{array}{c}\text { Early }(<72 \mathrm{hr}) \\
\text { or late-onset } \\
\quad(>72 \mathrm{hr}) \\
\text { hypocalcemia }\end{array}$ & $\begin{array}{l}\text { Neurological } \\
\text { symptoms and } \\
\text { signs }\end{array}$ & $\begin{array}{l}\text { Other } \\
\text { symptoms } \\
\text { and signs }\end{array}$ & $\begin{array}{c}\text { Age when PTH } \\
\text { values returned } \\
\text { normal }\end{array}$ & Treatment & Reference \\
\hline 3 & $\begin{array}{c}10-11 \\
\text { days }\end{array}$ & M & NA & Japan & Late & Seizures & None & $\begin{array}{c}\text { Before } 6 \text { months } \\
\text { of life }\end{array}$ & $\begin{array}{l}\text { Calcium and } \\
\text { calcitriol }\end{array}$ & $\begin{array}{c}\text { Minagawa et al. }{ }^{81} \\
\text { (1995) }\end{array}$ \\
\hline 1 & 21 days & $\mathrm{F}$ & NA & Oman & Late & Seizures & None & NA & $\begin{array}{l}\text { Calcium and } \\
\text { calcidiol }\end{array}$ & $\begin{array}{c}\left.\text { Manzar }{ }^{9}\right) \\
(2001)\end{array}$ \\
\hline 1 & 2 days & M & NA & India & Early & $\begin{array}{c}\text { Multifocal } \\
\text { seizures }\end{array}$ & None & NA & $\begin{array}{l}\text { Calcium and } \\
\text { calcitriol; } \\
\text { phenobarbitone } \\
\text { and phenytoin }\end{array}$ & $\begin{array}{c}\text { Sajitha et al. } \\
\qquad(2003)\end{array}$ \\
\hline 1 & 4 days & M & NA & India & Early & Seizures & None & NA & $\begin{array}{l}\text { Calcium and } \\
\text { calcitriol }\end{array}$ & $\begin{array}{c}\text { Narang et al. }{ }^{11)} \\
\text { (2006) }\end{array}$ \\
\hline 1 & 3 days & $\mathrm{F}$ & NA & Turkey & Early & Jitteriness & Natal teeth & $\begin{array}{c}\text { Before } 5 \text { months } \\
\text { of life }\end{array}$ & $\begin{array}{c}\text { Calcium and } \\
\text { vitamin D analog }\end{array}$ & $\begin{array}{l}\text { KoKlu et al. }{ }^{12)} \\
(2007)\end{array}$ \\
\hline 5 & $\begin{array}{c}25 \pm 26 \\
\text { days }\end{array}$ & M & $\begin{array}{l}35,36,36 \\
38,40\end{array}$ & Taiwan & Late & $\begin{array}{c}3 \text { Patients: focal } \\
\text { generalized } \\
\text { seizures, } \\
\text { jitteriness }\end{array}$ & $\begin{array}{l}2 \text { Patients: } \\
\text { respiratory } \\
\text { distress } \\
\text { after birth }\end{array}$ & NA & $\begin{array}{l}\text { Calcium/magnesium } \\
\text { supplementation } \\
\text { and reduction of } \\
\text { phosphorus intake }\end{array}$ & $\begin{array}{l}\text { Lee et al. }{ }^{13)} \\
\text { (2008) }\end{array}$ \\
\hline 4 & $\begin{array}{c}10-40 \\
\text { days }\end{array}$ & NA & NA & India & Late & $\begin{array}{c}\text { Multifocal } \\
\text { seizures }\end{array}$ & None & $\begin{array}{l}\text { Normal during } \\
\text { follow-up (not } \\
\text { specified when) }\end{array}$ & $\begin{array}{l}\text { Calcium and } \\
\text { calcitriol }\end{array}$ & $\begin{array}{l}\text { Patra et al. }{ }^{14)} \\
(2010)\end{array}$ \\
\hline 1 & 2nd day & M & 35 & Turkey & Early & None & $\begin{array}{l}\text { Calcinosis } \\
\text { cutis }\end{array}$ & $\begin{array}{l}\text { Normal at } 3 \\
\text { months of life }\end{array}$ & $\begin{array}{c}\text { Calcium and } \\
\text { vitamin D analog }\end{array}$ & $\begin{array}{l}\text { Ergin et al. }{ }^{15)} \\
(2011)\end{array}$ \\
\hline 1 & $\begin{array}{l}20 \text { hours } \\
\text { of life }\end{array}$ & M & 37 & Italy & Early & $\begin{array}{c}\text { Multifocal } \\
\text { seizures }\end{array}$ & None & $\begin{array}{c}\text { Normal at } \\
1 \text { month of life }\end{array}$ & Calcium and calcidiol & Our group \\
\hline
\end{tabular}

PTH, parathyroid hormone; NA, not available. 
factors (prematurity and/or intrauterine growth retardation, maternal diabetes, birth asphyxia, maternal assumption of antiepileptic drugs) were excluded. Persistent hypocalcemia with hyperphosphatemia associated with high PTH levels suggested a diagnosis of pseudohypoparathyroidism (probably a PHP type Ib in consideration of persistent hypocalcaemia, hyperphosphatemia, and high serum PTH levels without any stigmata of $\mathrm{AHO}$ and other hormone resistance). However, no stigmata of PHP were noted on the clinical examination. The transient nature of the condition was confirmed by the resolution of hypocalcemia after 8 days of supplementation.

In conclusion, transient PHP is an uncommon disorder in newborns and should be considered in newborns with persistent hypocalcemia and hyperphosphatemia despite calcium supplementation. We propose that transient PHP of the newborn (ntPHP) might be included among Inactivating PTH/ PTH-related protein signaling disorders (iPPSDs) as defined by the new classification of the EuroPHP Network. To the best of our knowledge, this is the first report in which the new classification has been applied to a case of ntPHP. Immature PTH1R signaling could play a key role in this condition. Further research in this population is needed to better understand PTH physiology in newborn development.

\section{Ethical statement}

The authors declare that they have followed the protocols of their Institutional Review Board on the publication of the patient's data and the Helsinki Declaration; no patient is recognizable from data within this article. We obtained written informed consent from the patient's parents beforehand in order to report these findings.

\section{Conflict of interest}

No potential conflict of interest relevant to this article was reported.

\section{Acknowledgments}

The authors would like to thank Dr. Samuele Naviglio (Institute for Maternal and Child Health IRCCS "Burlo Garofolo," Trieste, Italy) for his helpful advice.

\section{References}

1. Mantovani G. Clinical review: pseudohypoparathyroidism: diagnosis and treatment. J Clin Endocrinol Metab 2011;96:3020-30.

2. Albright F, Burnett CH, Smith CH, Parson W. Pseudohypoparathyroidism: an example of "Seabright-Bantam sindrome." Endocrinology 1942;30:922-32.

3. Bertino E, Spada E, Occhi L, Coscia A, Giuliani F, Gagliardi L, et al. Neonatal anthropometric charts: the Italian neonatal study compared with other European studies. J Pediatr Gastroenterol Nutr 2010;51:353-61.

4. Mantovani G, Spada A. Mutations in the Gs alpha gene causing hormone resistance. Best Pract Res Clin Endocrinol Metab 2006;20:501-13.

5. Bastepe M. The GNAS locus and pseudohypoparathyroidism. Adv Exp Med Biol 2008;626:27-40.

6. Turan S. Current nomenclature of pseudohypoparathyroidism: inactivating parathyroid hormone/parathyroid hormone-related protein signaling disorder. J Clin Res Pediatr Endocrinol 2017;9(Suppl 2):58-68.

7. Thiele S, Mantovani G, Barlier A, Boldrin V, Bordogna P, De Sanctis L, et al. From pseudohypoparathyroidism to inactivating PTH/PTHrP signalling disorder (iPPSD), a novel classification proposed by the EuroPHP network. Eur J Endocrinol 2016;175:P1-17.

8. Minagawa M, Yasuda T, Kobayashi Y, Niimi H. Transient pseudohypoparathyroidism of the neonate. Eur J Endocrinol 1995;133:151-5.

9. Manzar S. Transient pseudohypoparathyroidism and neonatal seizure. J Trop Pediatr 2001;47:113-4.

10. Sajitha S, Krishnamoorthy PN, Shenoy UV. Psedohypoparathyroidism in newborn - a rare presentation. Indian Pediatr 2003;40:47-9.

11. Narang M, Salota R, Sachdev SS. Neonatal pseudohypoparathyroidism. Indian J Pediatr 2006;73:97-8.

12. Koklu E, Kurtoglu S. Natal teeth and neonatal transient pseudohypoparathyroidism in a newborn. J Pediatr Endocrinol Metab 2007;20:971.

13. Lee CT, Tsai WY, Tung YC, Tsau YK. Transient pseudohypoparathyroidism as a cause of late-onset hypocalcemia in neonates and infants. J Formos Med Assoc 2008;107:80610 .

14. Patra S, Singh V, Pemde HK, Chandra J. Case series of neonatal hypocalcemia due to pseudohypoparathyroidism. J Pediatr Endocrinol Metab 2010;23:1073-5.

15. Ergin H, Karaca A, Ergin S, Cördük N, Karabulut N. Calcinosis cutis in a newborn with transient pseudohypoparathyroidism. Indian J Pediatr 2011;78:1424-6. 